\title{
Latitudinal and Seasonal Changes in Intertidal Sea Surface Temperature Along the Atlantic Coast of Nova Scotia, Canada
}

\author{
Ricardo A. Scrosati * and Julius A. Ellrich \\ Department of Biology, St. Francis Xavier University, Antigonish, NS, Canada
}

Keywords: intertidal, sea surface temperature, SST, upwelling, wave exposure

\section{INTRODUCTION}

Sea surface temperature (SST) is a commonly monitored variable in marine sciences, because it plays a key role in several oceanographic processes (Stewart, 2008; Deser et al., 2010; Kämpf and Chapman, 2016) and influences marine species distribution (Sanford, 2014; Henderson et al., 2017; Vallée et al., 2019). In Atlantic Canada, studies documenting SST patterns have been prolific, especially in recent years. As a result, the basic patterns of spatial and temporal variation in SST are reasonably well understood for oceanic waters off Nova Scotia, particularly on the Scotian Shelf (Hutt et al., 2002; Cyr and Larouche, 2015; Loder and Wang, 2015; Hebert et al., 2016; Larouche and Galbraith, 2016; Richaud et al., 2016; Thomas et al., 2017; Greenan et al., 2018).

For intertidal environments along the Nova Scotia coast, however, the latitudinal and seasonal variation in SST remains largely unknown. This is so because the studies that have described SST patterns in waters off Nova Scotia (cited above) did not monitor intertidal environments. Moreover, for large stretches of the Nova Scotia coastline, SST data for coastal waters even up to $10 \mathrm{~km}$ from the shore are unavailable (Hebert et al., 2016; Richaud et al., 2016). Knowledge on intertidal SST patterns is important, for example, to predict changes in the biogeography of intertidal species as conditions change (Sagarin et al., 1999; Mieszkowska et al., 2006; Adey and Hayek, 2011; Khan et al., 2018). Therefore, in this Data Report, we document for the first time the latitudinal and seasonal variation of intertidal SST along the Nova Scotia coast. As satellite SST data are often a poor predictor of intertidal SST (Smale and Wernberg, 2009), we measured SST in-situ in intertidal environments. To describe latitudinal patterns, we took measurements at nine intertidal locations along this coast. To describe seasonal patterns, we focused on monthly changes in intertidal SST, following the approach used to describe basic offshore SST patterns (Loder and Wang, 2015; Larouche and Galbraith, 2016). To get a sense of the consistency of the latitudinal and seasonal patterns in intertidal SST, we took measurements for a period of 4.5 years. Overall, the goals of this Data Report are to identify the main latitudinal and seasonal patterns in intertidal SST and to provide the underlying data set to help advance coastal marine science in this region and to allow other researchers to make comparisons with other regions.

Received: 11 May 2020

Accepted: 29 June 2020

Published: 07 August 2020

Citation:

Scrosati RA and Ellrich JA (2020) Latitudinal and Seasonal Changes in Intertidal Sea Surface Temperature

Along the Atlantic Coast of Nova

Scotia, Canada.

Front. Mar. Sci. 7:592.

doi: 10.3389/fmars.2020.00592

\section{MATERIALS AND METHODS}

We measured intertidal SST every day from 1 May 2014 to 31 October 2018 (with a few exceptions noted below) at nine intertidal locations spanning the full extent of the Atlantic coast of mainland Nova Scotia, nearly $415 \mathrm{~km}$ (Figure 1). For ease of interpretation, these locations are hereafter referred to as L1-L9, from north to south: Glasgow Head (L1; 45.3203 N, 60.9592 W), Deming Island (L2; 45.2121 N, 61.1738 W), Tor Bay Provincial Park (L3; 45.1823 N, 61.3553 W), 


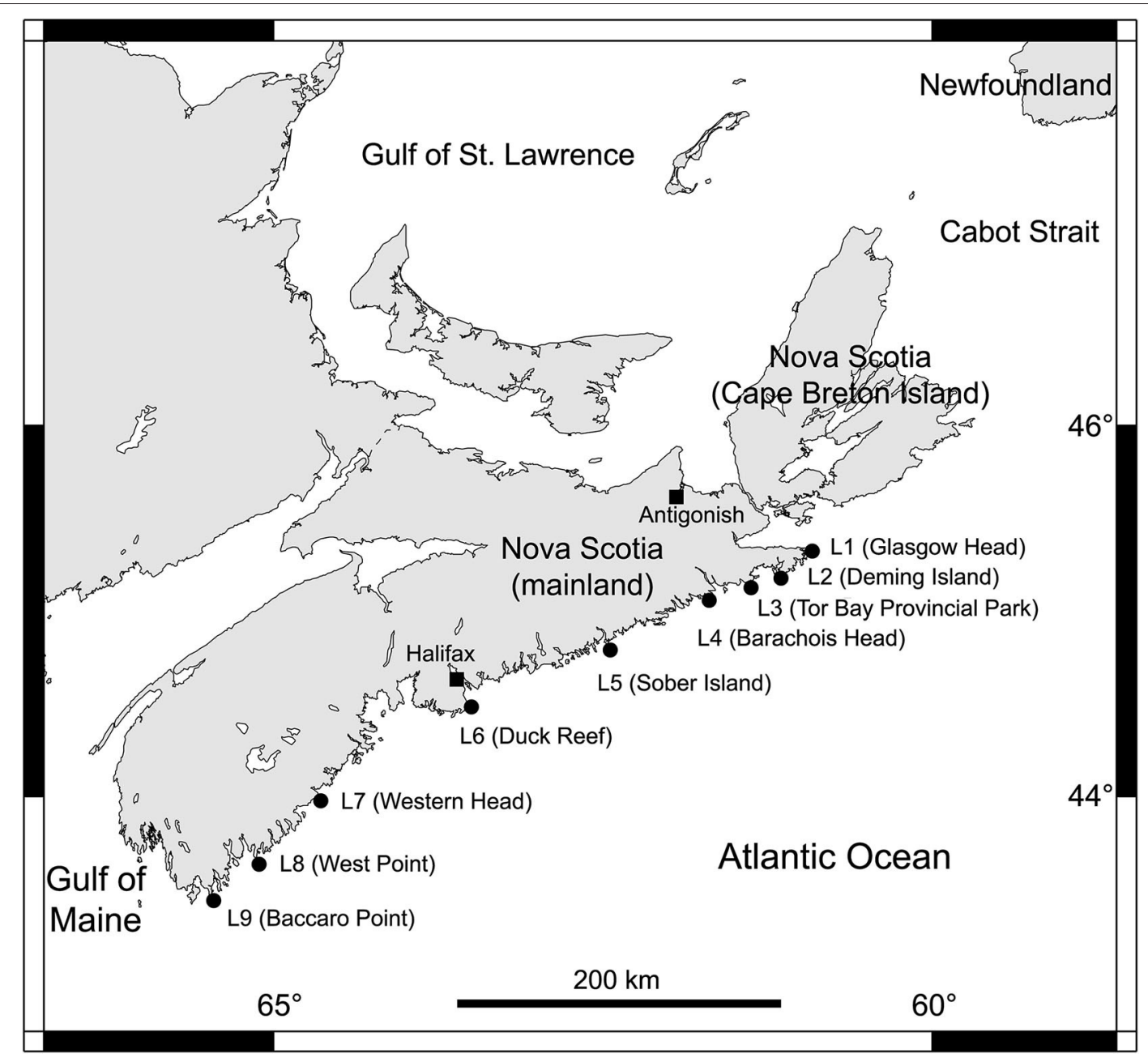

FIGURE 1 | Map indicating the position of the nine wave-exposed intertidal locations surveyed along the Atlantic coast of mainland Nova Scotia, Canada (see section Materials and Methods for their geographic coordinates).

Barachois Head (L4; 45.0890 N, 61.6933 W), Sober Island (L5; 44.8223 N, 62.4573 W), Duck Reef (L6; 44.4913 N, 63.5270 W), Western Head (L7; 43.9896 N, 64.6607 W), West Point (L8; $43.6533 \mathrm{~N}, 65.1309 \mathrm{~W}$ ), and Baccaro Point (L9; $43.4496 \mathrm{~N}$, $65.4697 \mathrm{~W})$. These intertidal locations are wave-exposed, as they face the open waters of the Atlantic Ocean without any physical obstructions. Values of daily maximum water velocity (an indication of wave exposure) measured with dynamometers (see design in Bell and Denny, 1994) in wave-exposed intertidal habitats from this coast range between 6 and $12 \mathrm{~m} \mathrm{~s}^{-1}$ (Hunt and Scheibling, 2001; Scrosati and Heaven, 2007; Ellrich and Scrosati, 2017). The substrate of the studied intertidal locations is stable bedrock.

We measured intertidal SST with submersible loggers (HOBO Pendant logger, Onset Computer, Bourne, MA, USA) that were kept attached to the intertidal substrate with plastic cable ties secured to eye screws drilled into the substrate, allowing almost no contact between the loggers and the substrate. We installed loggers for the first time in late April 2014 at L2-L9 and in late
April 2015 at L1. At each location, we installed two loggers several $\mathrm{m}$ apart from one another at an elevation just above the midintertidal zone. We set the loggers to record temperature every $30 \mathrm{~min}$. To maintain a continuous temperature record during the 4.5 years of the study, we replaced the loggers periodically. From the resulting time series of temperature, we extracted the values of daily SST, which we considered to be the temperature recorded closest to the time of the highest tide of each day, when the loggers were fully submerged in seawater. We determined the time of such tides using information (Tide and Current Predictor, 2020) for the tide reference stations that are closest to our intertidal locations: Canso $(45.3500 \mathrm{~N}, 61.0000 \mathrm{~W})$ for L1, Whitehead $(45.2333 \mathrm{~N}, 61.1833 \mathrm{~W})$ for L2, Larry's River $(45.2167 \mathrm{~N}, 61.3833 \mathrm{~W})$ for L3, Port Bickerton $(45.1000 \mathrm{~N}$, $61.7333 \mathrm{~W}$ ) for L4 and L5, Sambro (44.4833 N, 63.6000 W) for L6, Liverpool (44.0500 N, 64.7167 W) for L7, Lockport (43.7000 N, $65.1167 \mathrm{~W})$ for L8, and Ingomar $(43.5667 \mathrm{~N}, 65.3333 \mathrm{~W})$ for L9. For each studied intertidal location, daily SST was highly correlated between replicate loggers (mean $r=0.98, n=9$ 
locations), so we averaged the corresponding daily values to generate one time series of daily SST data for each location for the studied period (Scrosati and Ellrich, 2020a).

To identify basic latitudinal and seasonal trends in intertidal SST, we calculated monthly means of SST for each location using the corresponding values of daily SST (Scrosati and Ellrich, 2020a). We were able to calculate monthly SST means for all cases except between May 2014 and May 2015 for L1 (because we deployed loggers for the first time at L1 in late April 2015) and between October 2014 and May 2015 for L9 (because the loggers deployed at L9 in October 2014 were eventually lost to heavy surf and were only replaced in late April 2015). Because of logger loss at L1 caused by drift sea ice coming from the Gulf of St. Lawrence at the end of the 2017 winter, SST data are unavailable for L1 between 20 March and 12 April 2017, so we calculated monthly SST means for March and April 2017 for L1 based on the available dates.

With the monthly SST means, we calculated the annual SST range for each location and year as the difference between the corresponding highest and lowest monthly SST means. Annual SST ranges are unavailable for 2014 because of the unavailability of winter SST data for 2014, since this study began in the spring of 2014. Annual SST ranges are also unavailable for L1 and L9 in 2015 because no winter SST data were available for those locations in 2015, as noted above. Even though this study concluded on 31 October 2018, we calculated annual SST ranges for all locations for 2018 because, in this study, the highest monthly SST means consistently occurred in summer and the lowest monthly SST means consistently occurred in winter, periods that we did survey in 2018 at all locations.

For each location and year, we also calculated annual mean SST as the average of all corresponding monthly SST means. Because of the pattern of monthly coverage of SST described above, annual SST means for 2015 are available only for locations L2-L8 but for all nine locations in 2016 and 2017.

We note that SST anomalies cannot be reported because of the inexistence of previous long-term baselines for intertidal SST for our coast. In fact, as noted in the Introduction, ours is the first data set ever produced on intertidal SST at this level of spatial and temporal coverage for the area under scope.

\section{RESULTS}

The 4.5 years of data collection revealed relatively persistent latitudinal and seasonal trends in intertidal SST on the Atlantic coast of Nova Scotia. Warming toward the summer and cooling toward the winter occurred along the entire coast every year (Figure 2A). However, also every year, the latitudinal SST trend experienced a basic reversal between winter and summer. Such a reversal is most evident when viewing the coast at a relatively broad scale, as patchiness across neighboring locations along the coast naturally also occurred to some extent (Figure 2A). Overall, in winter months (considered for discussion purposes as January to March), monthly mean SST generally increased toward the south (Figure 2A), the lowest monthly mean recorded in winter at $\mathrm{L} 1$ being $-0.2^{\circ} \mathrm{C}$ but only $1.5^{\circ} \mathrm{C}$ at $\mathrm{L} 9$ (Figure $2 \mathrm{~B}$ ). In contrast, in summer months (July to September for discussion purposes), monthly mean SST generally decreased toward the south (Figure 2A), the highest monthly mean recorded in summer at $\mathrm{L} 1$ being $20.1^{\circ} \mathrm{C}$ but only $13.5^{\circ} \mathrm{C}$ at $\mathrm{L} 9$ (Figure $2 \mathrm{C}$ ). In spring (April to June) and fall (October to December), monthly mean SST generally showed intermediate values between those of winter and summer (Figure 2A).

As a result of those seasonal patterns along the coast, the annual SST range generally decreased toward the south: the highest value of annual SST range at L1 was $20.3^{\circ} \mathrm{C}$ but only $14.5^{\circ} \mathrm{C}$ at L9 (Figure 2D). Despite such a latitudinal trend for annual SST range, annual mean SST differed little among locations, as the maximum difference in annual mean SST between the two most different locations in any given year was only $0.8^{\circ} \mathrm{C}$ (Figure 2E).

\section{DISCUSSION AND IMPLICATIONS}

This is the first account of the latitudinal and seasonal variation of SST in wave-exposed intertidal environments along the Atlantic coast of Nova Scotia, Canada. The underlying data are particularly valuable because they were measured in situ, a better approach than those that measure SST remotely (e.g., with satellites), which are less reliable for intertidal habitats (Smale and Wernberg, 2009). Overall, the expected warming toward the summer and cooling toward the winter occurred along the entire coast every year. However, the latitudinal trend in intertidal SST exhibited basically a winter-to-summer reversal. Northern locations were typically cooler than southern locations in winter, while the reverse was generally true in summer. Again, such a pattern reversal is most evident when viewing the coast at a relatively coarse scale, as patchiness across neighboring locations along the coast also took place to some degree at times.

In winter, the northward decrease of intertidal SST could be mainly a result of latitudinal changes in heat flux from the atmosphere (Stewart, 2008; Deser et al., 2010; Shan et al., 2016), although other processes are also generally at play in coastal environments (Hebert et al., 2016; Larouche and Galbraith, 2016). Specifically for our coast, the extensive formation of sea ice across the Gulf of St. Lawrence every winter (Saucier et al., 2003) might also contribute to keeping intertidal SST low at our northern locations. Waters from the Gulf of St. Lawrence that eventually leave the gulf flow southwards following the coast of mainland Nova Scotia (Han et al., 1997; Hebert et al., 2016; Dever et al., 2018), reaching our northern locations first (Figure 1) before they have the chance to warm up. In this sense, it is interesting to note that winter values of intertidal SST at our northern locations were often near the freezing point of seawater (Scrosati and Ellrich, 2020a).

In summer, the southward decrease of intertidal SST may be a consequence of alongshore differences in coastal upwelling. On the Atlantic coast of Nova Scotia, upwelling-favorable winds are more common in summer than in winter (Garrett and Loucks, 1976; Dever et al., 2018) and, although alongshore differences in upwelling have not been studied in detail, they seem to exist. For example, Petrie et al. (1987) reported that seawater temperature 


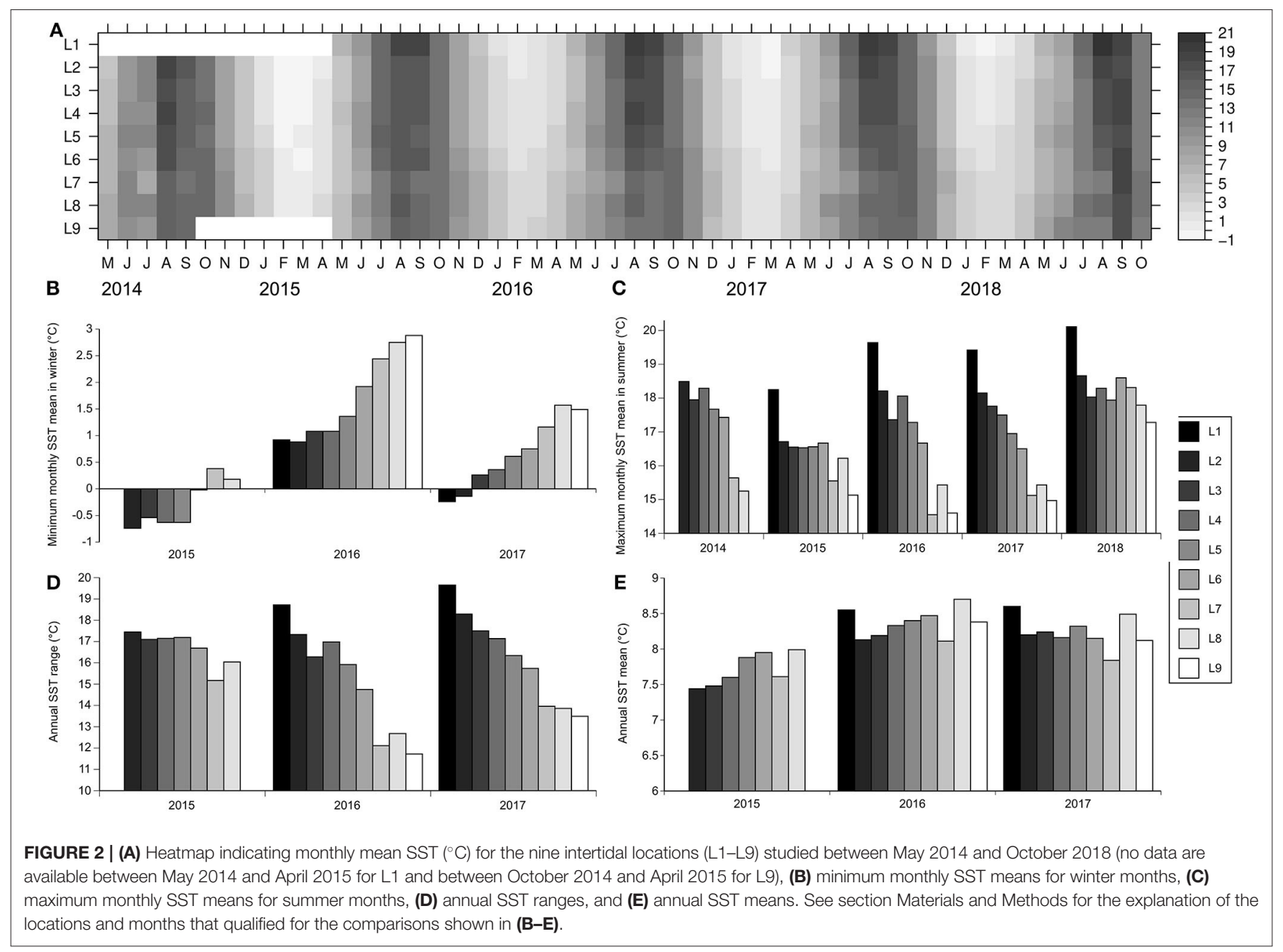

decreased between June and July 1984 at 6-20 m of depth near L6 and L7 because of wind-driven upwelling, while temperature increased in more northern waters on the mainland Nova Scotia coast for that depth range and period. More recently, Shan et al. (2016) have also referred to the occurrence of wind-driven upwelling on the southeastern Nova Scotia coast. A detailed analysis of daily changes in intertidal SST exceeds the objectives of this Data Report. However, the time series of intertidal SST generated for the nine studied locations (Figure 3) reveal basic differences in summer cooling between northern and southern locations. Summer cooling events were generally stronger in southern locations, especially at L6 and L7, where intertidal SST could drop by $10^{\circ} \mathrm{C}$ in 5-10 days, in some cases reaching SST values below $5^{\circ} \mathrm{C}$ (Figure 3). An analysis of coastal winds at L6 and L7 indicated that wind-driven upwelling explained the marked cooling observed at those locations in July 2014 (Scrosati and Ellrich, 2020b). Although persistent, the summer cooling signal that was often pronounced at L6 and L7 weakened progressively toward northern locations, especially at L1 and L2. In fact, at $\mathrm{L} 1$, intertidal SST never dropped below $10^{\circ} \mathrm{C}$ in the summer (Figure 3). We suggest to quantify upwelling along the Nova Scotia coast to formally evaluate its apparent influence on the alongshore SST trend in summer revealed by our data. When quantifying upwelling, other possible drivers to consider in addition to coastal wind, at least for our southernmost location, are tidal mixing and submarine topography, as these factors influence upwelling off southwestern Nova Scotia (Tee et al., 1993; Chegini et al., 2018). An additional factor to consider as a possible determinant of alongshore differences in SST could be air temperature. Overall, we hope that these considerations help orient future studies aiming to unravel the oceanographic and climatic drivers of the latitudinal changes in intertidal SST revealed by our surveys.

The SST data set described in this paper should also be helpful to understand patterns in intertidal species distribution along the Nova Scotia coast. Studies on intertidal biogeography have made important contributions to biogeographic theory (Sagarin and Gaines, 2002; Menge and Menge, 2013; Shanks and Morgan, 2018; Catalán et al., 2020) and marine species distribution depends on seawater temperature averages, extremes, and variability (Bennedetti-Cecchi et al., 2006; Somero, 2007; Blanchette et al., 2008; Lucey and Nye, 2010; Henderson et al., 2017). For Nova Scotia, there is already evidence that SST influences the biogeography of intertidal predator-prey systems 
L1

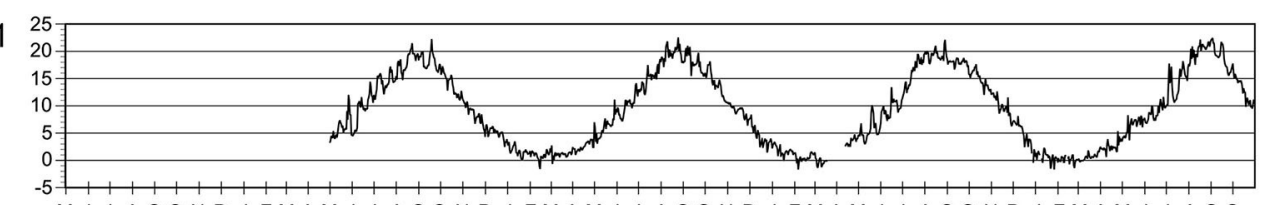

L2

MJ JASONDJ FMAMJ J ASONDJFMAMJ JASONDJFMAMJ J ASONDJFMAMJJASO

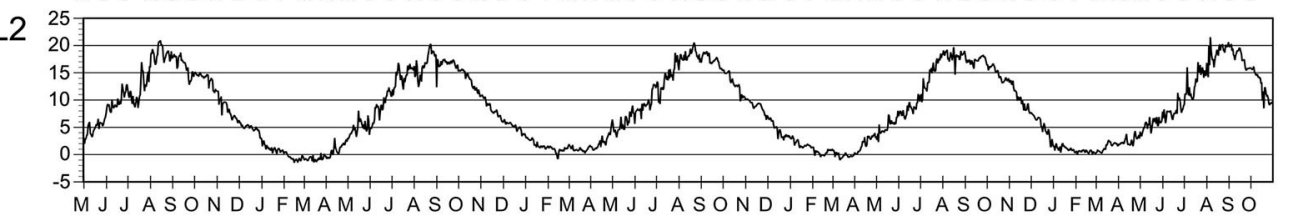

L3
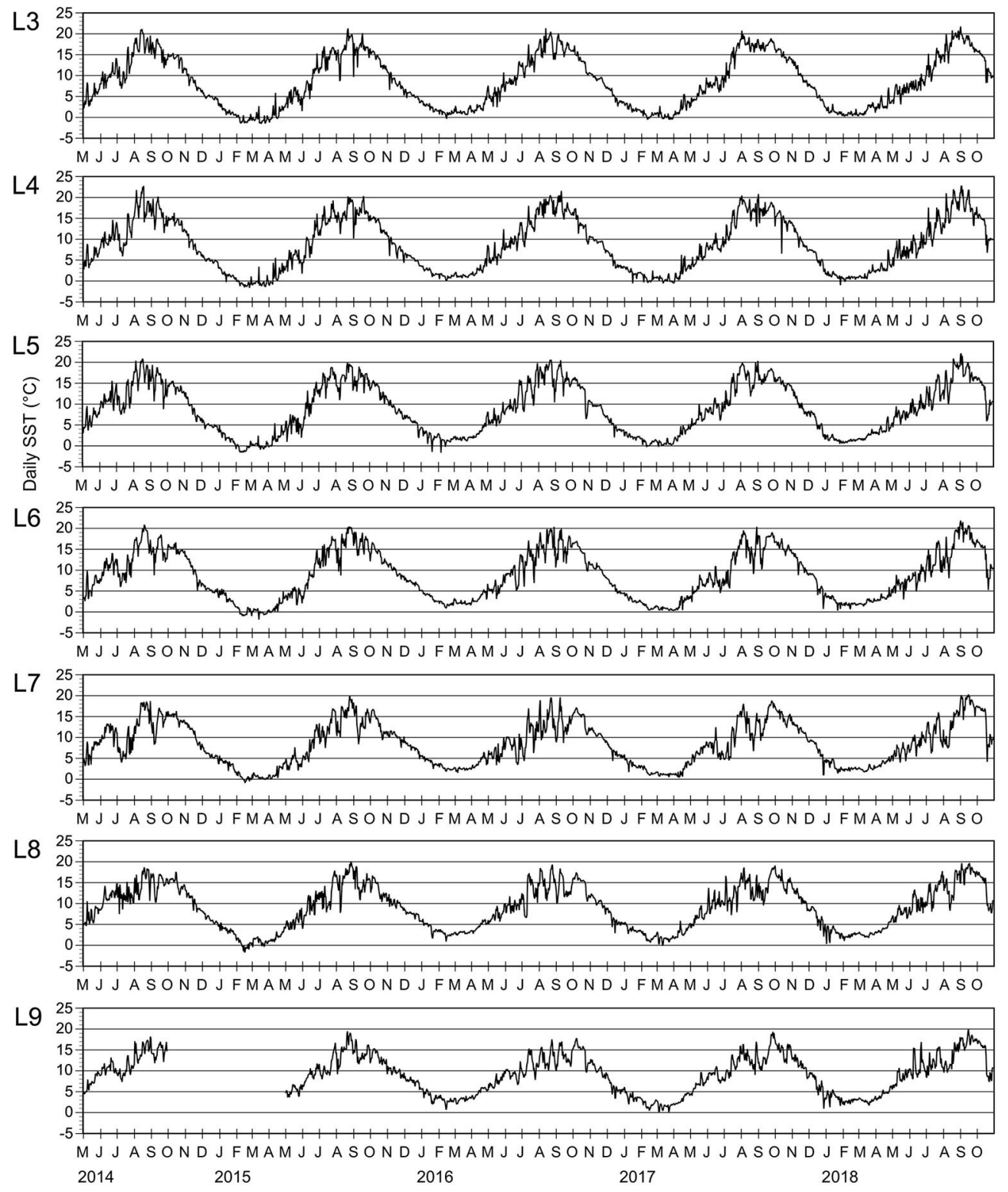

FIGURE 3 | Daily SST at the nine wave-exposed intertidal locations ( $L 1-L 9$, from north to south) surveyed along the Atlantic coast of mainland Nova Scotia between 1 May 2014 and 31 October 2018 (with exceptions as noted in section Materials and Methods). Each monthly tick mark along the $X$ axis is positioned on the first day of the month. 
along the coast (Scrosati and Ellrich, 2018). Knowledge of extreme temperatures recorded at specific locations is also important for coastal fisheries management (Larouche and Galbraith, 2016). In this sense, although mean annual SST varied little along the Nova Scotia coast, its annual variability increased with latitude, suggesting that thermal variability might be ecologically more important for species toward our northern locations. Additionally, the low winter values of SST at our northern locations might limit the abundance of species that thrive in warmer environments farther south on this coast.

Overall, this data set emerges as the first baseline on intertidal SST produced for the Nova Scotia coast. Given the interannual (e.g., NAO and ENSO) and decadal-scale (e.g., AMO) variability in climate and oceanography (Greene et al., 2013; Ting et al., 2014; Loder and Wang, 2015; Nalley et al., 2019; Chen et al., 2020) and the ongoing anthropogenic climate change that is predicted to alter SST patterns in eastern Canada (Saba et al., 2016; Greenan et al., 2018), further monitoring of this coast is encouraged to understand how those factors may influence intertidal SST and, ultimately, the variety of abiotic and biotic phenomena that depend on this key variable.

\section{DATA AVAILABILITY STATEMENT}

The dataset presented in this study can be found in an online repository. The name of the repository and accession number can

\section{REFERENCES}

Adey, W. H., and Hayek, L. A. C. (2011). Elucidating marine biogeography with macrophytes: quantitative analysis of the North Atlantic supports the thermogeographic model and demonstrates a distinct subarctic region in the northwestern Atlantic. Northeast. Nat. 18, 1-128. doi: 10.1656/045.018.m801

Bell, E. C., and Denny, M. W. (1994). Quantifying "wave exposure": a simple device for recording maximum velocity and results of its use at several field sites. $J$. Exp. Mar. Biol. Ecol. 181, 9-29. doi: 10.1016/0022-0981(94)90101-5

Bennedetti-Cecchi, L., Bertocci, I., Vaselli, S., and Maggi, E. (2006). Temporal variance reverses the impact of high mean intensity of stress in climate change experiments. Ecology 87, 2489-2499. doi: 10.1890/00129658(2006)87[2489:TVRTIO]2.0.CO;2

Blanchette, C. A., Miner, C. M., Raimondi, P. T., Lohse, D., Heady, K. E. K., and Broitman, B. R. (2008). Biogeographical patterns of rocky intertidal communities along the Pacific coast of North America. J. Biogeogr. 35, 1593-1607. doi: 10.1111/j.1365-2699.2008.01913.x

Catalán, A. M., Valdivia, N., and Scrosati, R. A. (2020). Interhemispheric comparison of scale-dependent spatial variation in the structure of intertidal rocky-shore communities. Ecosphere 11:e03068. doi: 10.1002/ecs2.3068

Chegini, F., Lu, Y., Katavouta, A., and Ritchie, H. (2018). Coastal upwelling off southwest Nova Scotia simulated with a high-resolution baroclinic ocean model. J. Geophys. Res. Oceans 123, 2318-2331. doi: 10.1002/2017JC013431

Chen, Z., Kwon, Y. O., Chen, K., Fratantoni, P., Gawarkiewicz, G., and Joyce, T. M. (2020). Long-term SST variability on the northwest Atlantic continental shelf and slope. Geophys. Res. Lett. 47:e2019GL085455. doi: 10.1029/2019GL085455

Cyr, F., and Larouche, P. (2015). Thermal fronts atlas of Canadian coastal waters. Atmos.-Ocean 53, 212-236. doi: 10.1080/07055900.2014.986710

Deser, C., Alexander, M. A., Xie, S. P., and Phillips, A. S. (2010). Sea surface temperature variability: patterns and mechanisms. Annu. Rev. Mar. Sci. 2, 115-143. doi: 10.1146/annurev-marine-120408-151453

Dever, M., Skagseth, Ø., Drinkwater, K., and Hebert, D. (2018). Frontal dynamics of a buoyancy-driven coastal current: quantifying buoyancy, wind, and be found below: https://www.doi.org/10.6084/m9.figshare.1227 8399.v1.

\section{AUTHOR CONTRIBUTIONS}

RS designed the study and wrote the manuscript. RS and JE led field work and JE data curation. Both authors contributed to the article and approved the final submitted version.

\section{FUNDING}

This study was funded by grants awarded to RS by the Natural Sciences and Engineering Research Council of Canada (NSERC Discovery Grant \#311624), the Canada Research Chairs program (CRC Grant \#210283), and the Canada Foundation for Innovation (CFI Leaders Opportunity Grant \#202034) and by a postdoctoral fellowship awarded to JE by the German Academic Exchange Service (DAAD fellowship \#91617093).

\section{ACKNOWLEDGMENTS}

We thank Alexis Catalán, Carmen Denfeld, Willy Petzold, Maike Willers for field assistance, Sebastián Luque for the $\mathrm{R}$ script to make the SST heatmap, and two reviewers for constructive comments on an earlier version of this paper. isopycnal tilting influence on the Nova Scotia current. J. Geophys. Res. Oceans 123, 4988-5003. doi: 10.1029/2017JC013338

Ellrich, J. A., and Scrosati, R. A. (2017). Maximum water velocities in wave-exposed rocky intertidal habitats from Deming Island, Atlantic coast of Nova Scotia, Canada. Pangaea online repository. doi: 10.1594/PANGAEA.880722

Garrett, C. J. R., and Loucks, R. H. (1976). Upwelling along the Yarmouth shore of Nova Scotia. J. Fish. Res. Board Can. 33, 116-117. doi: 10.1139/f76-013

Greenan, B. J. W., James, T. S., Loder, J. W., Pepin, P., Azetsu-Scott, K., Ianson, D., et al. (2018). "Changes in oceans surrounding Canada," in Canada's Changing Climate Report, eds E. Bush and D. S. Lemmen (Ottawa, ON: Government of Canada), 343-423.

Greene, C. H., Meyer-Gutbrod, E., Monger, B. C., McGarry, L. P., Pershing, A. J., Belkin, I. M., et al. (2013). Remote climate forcing of decadal-scale regime shifts in northwest Atlantic shelf ecosystems. Limnol. Oceanogr. 58, 803-816. doi: 10.4319/lo.2013.58.3.0803

Han, G., Hannah, C. G., Loder, J. W., and Smith, P. C. (1997). Seasonal variation of the three-dimensional mean circulation over the Scotian Shelf. J. Geophys. Res. 102, 1011-1025. doi: 10.1029/96JC03285

Hebert, D., Pettipas, R., Brickman, D., and Dever, M. (2016). Meteorological, sea ice, and physical oceanographic conditions on the Scotian Shelf and in the Gulf of Maine during 2015. DFO Canadian Science Advisory Secretariat, Document 2016/083 (Ottawa, ON).

Henderson, M. E., Mills, K. E., Thomas, A. C., Pershing, A. J., and Nye, J. A. (2017). Effects of spring onset and summer duration on fish species distribution and biomass along the northeast United States continental shelf. Rev. Fish. Biol. Fish. 27, 411-424. doi: 10.1007/s11160-017-9487-9

Hunt, H. L., and Scheibling, R. E. (2001). Patch dynamics of mussels on rocky shores: integrating process to understand pattern. Ecology 82, 3213-3231. doi: 10.1890/0012-9658(2001)082[3213:PDOMOR]2.0.CO;2

Hutt, D., Eert, J., Osler, J., Press, M., Sildam, J., Henschel, M., et al. (2002). "Comparison of sea surface temperatures on the Scotian Shelf derived from AVHRR and aerial bathythermograph surveys," in Proceedings of the 2002 IEEE International Geoscience and Remote Sensing Symposium, eds Institute of 
Electrical and Electronics Engineers (Toronto, ON: Institute of Electrical and Electronics Engineers), 2991-2993. doi: 10.1109/IGARSS.2002.1026846

Kämpf, J., and Chapman, P. (2016). Upwelling Systems of the World. A Scientific Journey to the Most Productive Marine Ecosystems. Cham: Springer, 433. doi: 10.1007/978-3-319-42524-5

Khan, A. H., Levac, E., Van Guelphen, L., Pohle, G., and Chmura, G. L. (2018). The effect of global climate change on the future distribution of economically important macroalgae (seaweeds) in the northwest Atlantic. Facets 3, 275-286. doi: 10.1139/facets-2017-0091

Larouche, P., and Galbraith, P. S. (2016). Canadian coastal seas and Great Lakes sea surface temperature climatology and recent trends. Can. J. Remote Sens. 42, 243-258. doi: 10.1080/07038992.2016.1166041

Loder, J. W., and Wang, Z. (2015). Trends and variability of sea surface temperature in the northwest Atlantic from three historical gridded datasets. Atmos.-Ocean 53, 510-528. doi: 10.1080/07055900.2015.1071237

Lucey, S. M., and Nye, J. A. (2010). Shifting species assemblages in the Northeast US Continental Shelf Large Marine Ecosystem. Mar. Ecol. Prog. Ser. 415, 23-33. doi: $10.3354 /$ meps 08743

Menge, B. A., and Menge, D. N. L. (2013). Dynamics of coastal meta-ecosystems: the intermittent upwelling hypothesis and a test in rocky intertidal regions. Ecol. Monogr. 83, 283-310. doi: 10.1890/12-1706.1

Mieszkowska, N., Kendall, M. A., Hawkins, S. J., Leaper, R., Williamson, P., Hardman-Mountford, N. J., et al. (2006). Changes in the range of some common rocky shore species in Britain - a response to climate change? Hydrobiologia 555, 241-251. doi: 10.1007/s10750-005-1120-6

Nalley, D., Adamowski, J., Biswas, A., Gharabaghi, B., and Hu, W. (2019). A multiscale and multivariate analysis of precipitation and streamflow variability in relation to ENSO, NAO, and PDO. J. Hydrol. 574, 288-307. doi: 10.1016/j.jhydrol.2019.04.024

Petrie, B., Topliss, B. J., and Wright, D. G. (1987). Coastal upwelling and eddy development off Nova Scotia. J. Geophys. Res. 29, 12979-12991. doi: 10.1029/JC092iC12p12979

Richaud, B., Kwon, Y. O., Joyce, T. M., Fratantoni, P. S., and Lentz, S. J. (2016). Surface and bottom temperature and salinity climatology along the continental shelf off the Canadian and U.S. east coasts. Cont. Shelf Res. 124, 165-181. doi: 10.1016/j.csr.2016.06.005

Saba, V. S., Griffies, S. M., Anderson, W. G., Winton, M., Alexander, M. A., Delworth, T. L., et al. (2016). Enhanced warming of the northwest Atlantic Ocean under climate change. J. Geophys. Res. Oceans 121, 118-132. doi: 10.1002/2015JC011346

Sagarin, R. D., Barry, J. P., Gilman, S. E., and Baxter, C. H. (1999). Climaterelated change in an intertidal community over short and long time scales. Ecol. Monogr. 69, 465-490. doi: 10.1890/0012-9615(1999)069[0465:CRCIAI]2. $0 . \mathrm{CO} ; 2$

Sagarin, R. D., and Gaines, S. D. (2002). Geographical abundance distributions of coastal invertebrates: using one-dimensional ranges to test biogeographic hypotheses. J. Biogeogr. 29, 985-997. doi: 10.1046/j.1365-2699.2002.00705.x

Sanford, E. (2014). "The biogeography of marine communities," in Marine Community Ecology and Conservation, eds M. D. Bertness, J. F. Bruno, B. R. Silliman, and J. J. Stachowicz (Sunderland: Sinauer), 131-163.

Saucier, F. J., Roy, F., Gilbert, D., Pellerin, P., and Ritchie, H. (2003). Modeling the formation and circulation processes of water masses and sea ice in the Gulf of St. Lawrence, Canada. J. Geophys. Res. 108:3269. doi: 10.1029/2000JC000686

Scrosati, R., and Heaven, C. (2007). Spatial trends in community richness, diversity, and evenness across rocky intertidal environmental stress gradients in eastern Canada. Mar. Ecol. Prog. Ser. 342, 1-14. doi: 10.3354/meps 342001

Scrosati, R. A., and Ellrich, J. A. (2018). Benthic-pelagic coupling and bottomup forcing in rocky intertidal communities along the Atlantic Canadian coast. Ecosphere 9:e02229. doi: 10.1002/ecs2.2229

Scrosati, R. A., and Ellrich, J. A. (2020a). Daily SST data from the Nova Scotia coast (2014-2018). figshare online repository. Available online at: https://doi.org/10. 6084/m9.figshare.12278399.v1.

Scrosati, R. A., and Ellrich, J. A. (2020b). Marked contrast in winddriven upwelling on the southeastern Nova Scotia coast in July of two years differing in ENSO conditions. Oceanol. Hydrobiol. Stud. 49, 81-87. doi: 10.1515/ohs-2020-0008

Shan, S., Sheng, J., Ohashi, K., and Dever, M. (2016). Assessing the performance of a multi-nested ocean circulation model using satellite remote sensing and in-situ observations. Satell. Oceanogr. Meteorol. 1, 39-59. doi: 10.18063/SOM.2016.01.004

Shanks, A. L., and Morgan, S. G. (2018). Testing the intermittent upwelling hypothesis: Upwelling, downwelling, and subsidies to the intertidal zone. Ecol. Monogr. 88, 22-35. doi: 10.1002/ecm.1281

Smale, D. A., and Wernberg, T. (2009). Satellite-derived SST data as a proxy for water temperature in nearshore benthic ecology. Mar. Ecol. Prog. Ser. 387, 27-37. doi: 10.3354/meps08132

Somero, G. (2007). "Heat stress," in Encyclopedia of Tidepools and Rocky Shores, eds M. W. Denny, and S. D. Gaines (Berkeley, CA: University of California Press), 266-270.

Stewart, R. H. (2008). Introduction to physical oceanography. Open Textbook Library. https://open.umn.edu/opentextbooks/textbooks/introduction-tophysical-oceanography

Tee, K. T., Smith, P. C., and LeFaivre, D. (1993). Topographic upwelling off southwest Nova Scotia. J. Phys. Oceanogr. 23, 1703-1726. doi: 10.1175/1520-0485(1993)023<1703:TUOSNS>2.0.CO;2

Thomas, A. C., Pershing, A. J., Friedland, K. D., Nye, J. A., Mills, K. E., Alexander, M. A., et al. (2017). Seasonal trends and phenology shifts in sea surface temperature on the North American northeastern continental shelf. Elem. Sci. Anth. 5:48. doi: 10.1525/elementa.240

Tide and Current Predictor (2020). Tidal Height and Current Site Selection. Available online at: http://tbone.biol.sc.edu/tide/index.html

Ting, M., Kushnir, Y., and Li, C. (2014). North Atlantic Multidecadal SST Oscillation: External forcing versus internal variability. J. Mar. Syst. 133, 27-38. doi: 10.1016/j.jmarsys.2013.07.006

Vallée, V., Villanueva, M. C., and Blanchard, F. (2019). Functional richness and turnover patterns reveal assembly rules structuring marine fish communities on the continental shelf of French Guiana. Mar. Ecol. Prog. Ser. 630, 183-195. doi: $10.3354 /$ meps 13129

Conflict of Interest: The authors declare that the research was conducted in the absence of any commercial or financial relationships that could be construed as a potential conflict of interest.

Copyright (๑) 2020 Scrosati and Ellrich. This is an open-access article distributed under the terms of the Creative Commons Attribution License (CC BY). The use, distribution or reproduction in other forums is permitted, provided the original author(s) and the copyright owner(s) are credited and that the original publication in this journal is cited, in accordance with accepted academic practice. No use, distribution or reproduction is permitted which does not comply with these terms. 